IT FOR SOCIETY, Vol. 05, No. 01

ISSN 2503-2224

\title{
SISTEM INFORMASI MONITORING DAN PERBAIKAN MESIN PRODUKSI BERBASIS ANDROID PADA PT KATSUSHIRO INDONESIA
}

\author{
Marsigit ${ }^{1}$ \\ Tjong Wansen ${ }^{2}$ \\ President University \\ Bekasi, Indonesia \\ ${ }^{2}$ wansen@president.ac.id
}

\begin{abstract}
Abstrak - Dalam usaha meningkatkan produktivitas, efisiensi, dan efektivitas dari sumber daya yang dimiliki suatu perusahaan harus terus melakukan inovasi-inovasi dalam proses produksinya. Pada zaman modern sekarang ini mesin produksi yang yang handal sangat membantu dalam proses produksi pemeliharaan dan perawatan yang tidak baik akan menghambat inovasi-inovasi proses produksi, kualitas dan kuantitas dari hasil produksi. Di sisi lain, dibutuhkan sistem otomasi yang dapat mencatat kinerja mesin produksi dan permasalahannya berupa Sistem Informasi Monitoring dan Perbaikan Mesin Produksi berbasis Android. Dengan adanya ini maka maintenance dapat lebih mudah dalam memonitor dan memperbaiki mesin-mesin yang bermasalah. Sistem ini juga meghasilkan laporan tentang permasalahan yang terjadi pada mesin produksi yang langsung diterima pihak maintenance.
\end{abstract}

\section{Latar Belakang}

Masalah produksi pada mesin produksi sering dijumpai pada setiap perusahaan baik dalam skala besar,menengah maupun skala kecil. Masalah produksi tersebut sering tidak diketahui cepat oleh pihak-pihak tertentu terutama pihak atasan seperti manager, kepala bagian dan maintenance. Pemberitahuan masalah pada produksi mesin diperlukan cepat, agar dapat segera ditindak lanjuti. Penanganan masalah produksi dapat meningkatkan efektivitas produksi, hal ini berhubungan erat dengan tingkat keberhasilan suatu perusahaan,apabila tingkat efektivitas perusahaan tersebut tinggi, maka suatu perusahaan dapat dikatakan sukses dalam hal memenuhi target produksi.
PT Katsushiro Indonesia memiliki ratusan mesin produksi yang terdiri dari mesin CNC,Cutting,Milling maupun mesin las. Kinerja produksi pada mesin sangat mempengaruhi dalam peningkatan efektivitas produksi barang yang dihasilkan,sehingga semakin banyak dan semakin cepat produksi yang di hasilkan maka akan menguntungkan bagi perusahaan PT Katsushiro Indonesia. Kejadian kerusakan sebuah mesin produksi di PT Katsushiro Indonesia seringkali dijumpai. Operator mesin diberikan penjadwalan dalam pengecekan satu persatu kondisi mesin produksi dan mencatat pada buku catatan yang ada di setiap mesin untuk membuat histori mesin selama ini. Ketika operator menemukan masalah pada mesin produksi segera membuat form maintenance request yang ada di setiap line produksi dan di beritahukan kepada teknisi mesin atau maintenance untuk segera diperbaiki.

Dalam penanganan masalah mesin produksi tersebut ada beberapa kendala yang terjadi seperti :

1. Ketersediaan form maintenance request yang tidak merata di setiap line produksi sehingga operator mesin harus mencari dulu ke line lain sehingga tidak efisien dan efektif dalam bekerja dan waktu.

2. Lokasi ruang maintenance yang jauh dari line produksi akan membuat waktu perbaikan menjadi lama dikarenakan operator mesin harus menyerahkan ke ruang maintenance yang jaraknya agak jauh.

3. Keterbatasan teknisi mesin atau maintenance sehingga mereka jarang standby diruang maintenance dikarenakan banyaknya kerjaan mereka yang mana 1 orang teknisi bisa menangani 5 sampai 10 mesin. Hal ini 
menyebabkan form maintenance request yang ada diraung maintenance tidak terkontrol oleh mereka sehingga penanganan mesin menjadi agak lama.

\section{Batasan Masalah}

Supaya pembahasan masalah yang dilakukan dapat terarah dengan baik dan tidak menyimpang dari pokok permasalahan.

Berikut adalah batasan masalah yang akan dibahas, yaitu:

1. Aplikasi dibuat di atas platform android sehingga dimungkinkan hanya dapat dijalankan pada smartphone barbasis android.

2. Hanya membahas masalah sistem informasi yang berhubungan dengan monitoring dan perbaikan mesin produksi , seperti : operator, maintenance, data kerusakan, dan masalah perbaikan.

3. Sistem informasi ini tidak membahas keamanan database dan keamanan jaringan yang digunakan untuk kebutuhan aplikasi.

\section{Tujuan}

Tujuan yang hendak dicapai dengan adanya sistem ini adalah sebagai berikut:

1. Membuat program terintegrasi yang dapat memudahkan proses monitoring proses produksi.

2. Membangun sistem yang dapat mempermudah operator mesin produksi dalam melaporkan masalah yang terjadi.

3. Membangun sistem yang dapat mempermudah teknisi atau maintenance dalam mengontrol dan memperbaiki mesin produksi.

\section{Metode Pengembangan}

Metodologi yang digunakan dalam mengembangkan sistem ini adalah Rapid Application Development (RAD) yaitu strategi siklus hidup yang ditujukan untuk menyediakan pengembangan yang jauh lebih cepat dan mendapatkan hasil dengan kualitas yang lebih baik dibandingkan dengan hasil yang dicapai melalui siklus tradisional. RAD terdiri dari beberapa fase antara lain:

1. Analisis

2. Desain

3. Pengkodean dan Pengujian

4. Implementasi dan Pemeliharaan

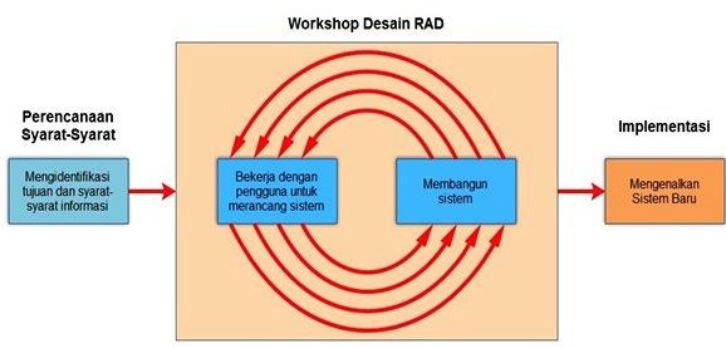

Gambar 1. Siklus RAD

\section{Analisis Proses Bisnis}

Penjelasan proses bisnis Sistem Infromasi Monitoring dan Perbaikan Mesin Produksi Berbasis Android pada PT Katsushiro Indonesia :

1. Admin menambahkan data area plant.

2. Admin menambahkan data mesin.

3. Admin menambahkan data teknisi.

4. Operator melakukan login untuk masuk ke dashboard user.

5. Operator mengklik input problem mesin untuk membuat laporan kerusakan yang terjadi pada mesin produksi.

6. Operator mengklik all data untuk melihat semua kerusakan mesin yang telah dilaporkan ke maintenance.

7. Operator mengklik issue submit untuk melihat status kerusakan mesin yang belum diperbaiki maintenance

8. Operator mengklik issue plan melihat status mesin yang sedang diperbaiki maintenance.

9. Operator mengklik issue finish untuk melihat status mesin yang sudah diperbaiki maintenance.

10. Maintenance melakukan login untuk masuk ke dashboard maintenance.

11. Maintenance mengklik icon tambah untuk melihat semua informasi kerusakan mesin.

12. Maintenance mengklik issue submit untuk menuju menu input planning maintenance kemudian mengisi nama teknisi dan tanggal rencana perbaikan.

13. Maintenance mengklik issue plan untuk menuju menu input finish ticket kemudian mengisi tanggal selesai perbaikan dan langkah perbaikan yang dilakukan. 
14. Maintenance mengklik issue finish untuk menuju menu tiket selesai untuk melihat detail perbaikan yang telah dikerjakan.

15. Maintenance melakukan logout untuk keluar dari sistem.

\section{Program Aplikasi}

Aplikasi android ini diharapkan mampu menampilkan:

1. Login form, dalam hal otorisasi untuk mengelola hak akses.

2. Ada 3 (tiga) user dalam sistem ini, yaitu: admin,operator dan maintenance.

3. Menu yang dapat diakses admin yaitu all data, issue submit, issue plan, issue finish, data area plant, data teknisi dan data mesin.

4. Pada menu data area plant admin dapat menambahkan data area baru,mengedit data area dan menghapus data plant.

5. Pada menu data teknisi admin dapat menambahkan data teknisi baru ,mengedit dan menghapus data teknisi.

6. Pada menu data mesin admin dapat menambahkan data mesin baru,mengedit dan menghapus data mesin.

7. Pada menu issue submit operator hanya dapat melihat detail laporan masalah kerusakan dan melihat status perbaikan.

8. Pada menu issue plan operator hanya dapat melihat detail laporan masalah kerusakan dan melihat status progress perbaikan.

9. Pada menu issue finish operator hanya dapat melihat detail laporan masalah kerusakan dan melihat status perbaikan mesin yang telah selesai dikerjakan maintenance.

10. Pada menu issue submit maintenance dapat melihat detail laporan masalah kerusakan,menginput menu perbaikan dan merubah status perbaikan menjadi issue plan.

11. Pada menu issue plan maintenance dapat melihat detail laporan masalah kerusakan,menginput menu action perbaikan dan merubah status issue finish.

12. Pada menu issue finish maintenance dapat melihat detail laporan masalah kerusakan dan solusi perbaikan dari teknisi.

13. Logout form, untuk keluar dari sistem.

\section{Sistem Pengujian}

Pengujian dilakukan dengan memasukkan data dengan kondisi tertentu pada sistem. Pengujian ini dibagi menjadi dua skenario yaitu Tes Positif dan Tes Negatif. Tes positif dilakukan dengan memasukkan data yang benar, sedangkan tes negatif dilakukan dengan memasukkan data yang salah.

\section{Kesimpulan Hasil Pengujian}

Dari hasil pengujian, umumnya menunjukkan bahwa sistem sudah berjalan dengan baik dan sesuai dengan apa yang diharapkan dalam proses pengujian. Menurut tes positif dan tes negatif, dapat ditarik kesimpulan bahwa sistem dapat memvalidasi masukan dari pengguna dan respon sistem terhadap masukan pengguna yang sesuai dengan skenario sistem.

\section{Kesimpulan}

Berdasarkan hasil pengumpulan, pengolahan, analisis data dan perancangan sistem, maka dapat diambil kesimpulan bahwa:

1. Sistem informasi monitoring dan perbaikan mesin produksi berbasis android pada PT Katsushiro Indonesia dapat mempermudah operator mesin dalam melaporkan segala masalah kerusakan mesin produksi ke pihak maintenance sehingga kerusakan mesin produksi segera ditangani secara lebih efektif dan efisien.

2. Sistem informasi dengan database terpusat membantu pihak maintenance dalam hal penyimpanan, pencarian serta pengolahan data. Sistem informasi yang dibuat membantu mengurangi kesalahan dalam proses pencatatan, serta mempermudah dalam hal pemantauan data tindakan perbaikan.

3. Tampilan sistem informasi berbeda untuk masing-masing pengguna sesuai dengan hak akses dan tingkat otoritasnya. Hal tersebut berguna untuk menghindari kesalahan input data serta memudahkan pengguna untuk menjalankan tugasnya masing-masing.

4. Dashboard yang menampilkan laporan kerusakan mesin,laporan mesin yang sedang diperbaiki dan laporan kerusakan mesin yang telah selesai diperbaiki dapat diakses oleh maintenance secara realtime. Laporan-laporan tersebut bisa menjadi pendukung maintenance dalam menentukan langkah selanjutnya untuk peningkatan pelayanan perbaikan mesin.

\section{Daftar Pustaka}

[1] Supriatno Suprianto, Dodit. Rini Agustina. 2012. Pemrograman Aplikasi Android. Penerbit Mediakom, Yogyakarta. 
[2] Stephanus Hermawan S., 2011, Mudah membuat Aplikasi Android. Andi,Yogyakarta.

[3] Dhanta, Rizky. 2009. Pengantar Ilmu Komputer . Surabaya: Indah

[4] Safaat Nazruddin H., 2011, Pemrograman Aplikasi Mobile Smartphone dan Tablet PC Berbasis Android, Bandung.

[5] Romeo, 2003, Testing dan Implementasi Sistem, Edisi Pertama, STIKOM, Surabaya.

[6] Kendall, K.E dan Kendall, J.E. 2003. Analisis dan Perancangan Sistem. Jakarta. Prehallindo.

[7] Kristanto, H. (2004). Konsep \& Perancangan Database. Yogyakarta: Andi.

[8] Daryus. 2008. Manajemen Pemeliharaan Mesin. Jakarta: Universitas Darma.

[9] Assauri, S. 2004. Manajemen Produksi dan Operasi. Jakarta: FEUI.

[10] Sidik, B., \& Pohan, H. I. (2007). Pemrograman WEB dengan HTML. Bandung: Informatika.
[11] Sholiq. 2006. Pemodelan Sistem informasi Berorientasi Objek dengan $U M L$.Yogyakarta: Graha Ilmu.

[12] Jogiyanto. 2005. Analisis dan Desain Sistem Informasi. Yogyakarta: Andi.

[13] Sutabri, T. (2012). Analisis Sistem Informasi. Yogyakarta: Andi Offset.

[14] Hakim, Lukmanul. 2010. Membangun Web Berbasis PHP Dengan Framework CodeIgniter. Lokomedia: Yogyakarta. 